\title{
THOMAS PYNCHON'S “MORALITY AND MERCY IN VIENNA": MAJOR THEMES IN AN EARLY WORK
}

\section{Jacqueline Smetak}

\begin{abstract}
When we try to examine the mirror in itself we finally discover nothing but the things that it reflects. If we wish to group the things we touch nothing in the end but the mirror-This is the most general history of knowledge. The Dawn, Frederich Nietzsche
\end{abstract}

Understanding it is easy; the diffcult thing is to think within its limits.

Jorge Luis Borges

BORGES HAS WRITTEN that history is an interminable and perplexing dream with recurring forms, "perhaps nothing but forms." He says that humankind does not think anything new but returns again and again to the same ideas, enigmas, and riddles. In the works of Thomas Pynchon this general observation becomes specific. No matter how complex or perplexing Pynchon's fiction may be, all of it centers on one idea-death. Pynchon expresses this idea of death through the structure of the double, the binary opposition, the not this and the not that, all pointing to the blank in the middle where meaning is like the navel of a Freudian dream. ${ }^{2}$

Pynchon works by word play and pun to create a multi-level, pluralistic text. As Roland Barthes would put it, in referring to the writerly text, "this text is a galaxy of signifiers, not a structure of signifieds." 3 What Pynchon's signifiers mean is never clear in that they can and do have several different and sometimes opposing meanings on both semantic and structural levels. According to Wolfgang Iser the ambiguity characteristic of Pynchon's fiction is inherent in the way we read a literary text. The blank or gap in the text, what Iser calls "negativity," is "the infrastructure of the literary text." It is the "nonformulation of the not-yet-comprehended" and the "link between the reader and the text." ${ }^{4} \mathrm{He}$ says: 
Whatever may be the individual contents which come into the world through a work of art, there will always be something which is never given in the world and which only a work of art provides: it enables us to transcend that which we are otherwise so inextricably entangled in-our own lives in the midst of the real world. Negativity as a basic constituent of communication is therefore an enabling structure. It demands a process of determining which only the subject can implement, and this gives rise to the subjective hue of literary meaning, but also to the fecundity of that meaning, for each decision taken has to stabilize itself against the alternatives which it has rejected. These alternatives arise both from the text itself and from the reader's own disposition-the former allowing different options, the latter different insights. ${ }^{5}$

In other words, the meaning resides not in what is said but in what is not said. What is said provides a way to get at what is meant, but is not the meaning itself. As Roland Barthes puts it:

the goal of literary work (of literature as work) is to make the reader no longer a consumer, but a producer of the text .... the writerly text is ourselves writing, before the infinite play of the world (the world as function [since nothing exists outside of the work, the work is the world]) is traversed, intersected, stopped, plasticized by some singular system ... which reduces the plurality of entrances, the opening of networks, the infinity of languages.... To interpret a text is not to give it a (more or less justified, more or less free) meaning, but on the contrary to appreciate what plural constitutes it. ${ }^{6}$

In the words of Stanley Fish "the place where sense is made or not made is the reader's mind rather than the printed page."7 For Fish, the meaning of a literary work is in the experience of reading it, not in some neat final answer which assumes the meaning to be "embedded in the artifact."

What Pynchon does, particularly in his novels V., The Crying of Lot 49, and Gravity's Rainbow, is to take what these critics call the process of reading or interpreting a text and make that the central theme of his fiction. The line of action in all three novels is a quest without an object for the quest, a search for meaning which uncovers no meaning. The insights the reader gleans from the futility of the quest is at the center of Pynchon's fiction. It is a process often represented by a movement from one place to another or by a complex series of puns and word games embedded in the texture of the language or by multi-dimensional symbols which cannot easily be explained. For example, Pynchon's first published story, "The Small Rain" (Cornell Writer 6, March 1959), involves a change of place, a movement between two worlds neither of which is satisfactory. This structure will reoccur in "Lowlands" in the contrast between the world of Dennis Flange's relentlessly rational wife and the garbage dump of Pig Bodine; in "Mortality and Mercy in Vienna," Cleanth Siegel as Wandering Jew and diplomatic courier; in "Entropy," Meatball's apartment versus Callisto's; in $V$., Profane's yo-yoing and Stencil's quest; in The Crying of Lot 49, with Oedipa Maas trapped between suburbia and W.A.S.T.E.; and in Gravity's Rainbow, in the tension between a "realistic" world depicted in painstakingly accurate detail and the absurd world of Prentice's imagination and of the Zone. 
Pynchon's second story, "Mortality and Mercy in Vienna" (Epoch 9, Spring 1959), is about death, salvation, and madness and it uses the double as its primary image, the triple as its secondary. The story line is relatively simple. A junior diplomat, Cleanth Siegel, shows up at the Washington, D.C. apartment of David Lupescu expecting a party. Siegel arrives before everyone else but no matter, Lupescu, who happens to look exactly like Siegel, is already sick of the party, calls Siegel "a sign, and a deliverance," nails a pig foetus reeking of formaldehyde to the molding above the kitchen door, designates Siegel "host," pun intended, and bolts out the front door into the April rain. Then the guests arrive. They are all, in the words of Cleanth Siegel, "raving lunatics" who latch onto him as if he were a priest and a father confessor, a role Lupescu had often played, telling him secrets no one wants to hear:

She went on in the same way for fifteen minutes more, laying bare, like a clumsy brain surgeon, synapses and convolutions which never should have been exposed, revealing for Siegel the anatomy of a disease more serious than he had suspected: the badlands of the heart, in which shadows, and crisscrossed threads of inaccurate self analysis and Freudian fallacy, and passages where the light and perspective were tricky, all threw you into that heightened hysterical edginess of the sort of nightmare it is possible to have where your eyes are open and everything in the scene is familiar, yet where, Hickering behind the edge of the closet door, hidden under the chair in the corner, is this je ne sais quoi de sinistre which sends you shouting into wakefulness. (MMV 205)

The party becomes progressively more awful until Siegel spots an Ojibwa Indian, Irving Loon, standing beside the pig foetus "like some momento mori, withdrawn and melancholy." According to Loon's mistress, Debbie Considine, he is suffering from "a divine melancholia" but, as only Siegel knows, what Loon is really suffering from is the Windigo psychosis, a paranoid delusion that he is "a mile-high skeleton made of ice" and all the people around him are "succulent, juicy, fat" beavers. Siegel awakens the monster by whispering "Windigo" in Loon's ear, then retires to the kitchen to wait. Siegel is the only one who knows what will happen in the next few minutes and he can bring to these people "a very tangible salvation" or he can leave. When he sees Loon take down one of Lupescu's Browning Automatics and begin to load it, there is a moment of tension between his Jesuit half which acts and sets things in motion and his Jewish half which, passively, accepts and mourns. But it is only a moment. Then, as Lupescu had given the party to him, Siegel gives it to Irving Loon and quietly, unobtrusively leaves. "It was not until he had reached the street that he heard the first burst of the BAR fire" (MMV 213).

The basic structure of the story is a double transaction, the passing on of the party, involving three people, David Lupescu, Cleanth Siegel and Irving Loon. The double, according to Freud, Otto Rank, and James G. Frazer refers to death, being either a charm against it or an indicator of it. ${ }^{9}$ The triple or trinity (Lupescu's apartment number, for example, is $3 \mathrm{~F}$ ) refers to Christ and the three men are an imitation of Him on some level, as priest, 
as confessor, as "an outward manifestation ... of the divine body and blood" (MMV 199). The symbol for this is the foetal pig carried by Lupescu, mirrored in Siegel's scotch bottle- "They faced each other like slightly flawed mirror images-different patterns of tweed, scotch bottle and pig foetus, but no discrepancy in height" (MMV 197-98)—and hanging beside Irving Loon.

The pig is traditionally associated with Kore or dema figures; corn goddesses such as Demeter or Persephone, or killed, dismembered, buried, resurrected, and eaten gods such as Dionysus, Bacchus, or Christ. Pigs were seen as the embodiment of the god or goddess and were sacrificed in the spring and either scattered over the fields or eaten by the villagers. ${ }^{10}$ According to Joseph Cambell in his book The Masks of God: Primitive Mythology, the ritual killing of the dema in whatever form is a "divine drama," a "cosmic tragedy of crime and punishment" which does not cut man off, but rather, through "man's act of violence" makes the dema "the very substance of his life." It is the introduction of death and sex into a timeless mythical world "as the basic correlates of temporality." 11 The pig in "Mortality and Mercy in Vienna" is, of course, dead and is associated with both sex and Christ. As Lupescu notes, "Dada exhibit in Paris on Christmas Eve, 1919 . . used one in place of mistletoe" (MMV 198). The world of Lupescu's apartment is static. "I don't know anybody," Siegel says, " . . A All the old crowd seems to have drifted away." Lupescu agrees with him: “" 'I know,' he said grimly. Big turnover. But the types are constant'” (MMV 198). In preChristian mythology, these events are cyclical. In Christian mythology they are linear, emphasizing the "guilt of man in having brought it about" and pointing toward a final judgement. ${ }^{12}$ Lupescu, Siegel, and Loon, as mirrors of each other are clearly dema or Christ figures. Siegel is designated such near the beginning of the story:

"It's all yours," [Lupescu] said. "You are now the host. As host you are a trinity: (a) receiver of guests ... (b) an enemy and (c) an outward manifestation, for them, of the divine body and blood." (MMV 199)

As host, Siegel is both host in the conventional sense and Christ (the Communion wafer), and as such, should be dismembered and eaten by those who seek from him salvation, in this case, the guests who confess to him the distasteful details of their lives, their intrigues and their petty affairs. But he is also an enemy, a contradiction of his office as host. The ambiguity of his position is mirrored in the ambiguity inherent in the symbolism of the pig, an animal which is both sacred (associated with fertility and resurrection) and profane (unclean). James G. Fraser explains this by saying the "difference of opinion points to a state of religious thought and feeling in which the ideas of sanctity and uncleanness are not yet differentiated, and which is best indicated by the word taboo." 13 
The dema in this story is not killed. The guests are killed and underlying the massacre is a violated taboo. Very little else could account for the blood bath's hideous inevitability or for the rising sense of horror the reader feels as the story proceeds. It is a horror which transcends the merely frightening. It is what Freud calls the "uncanny" and which he defines as "that class of the terrifying which leads back to something long known to us, once very familiar."14 Siegel uses similar words to describe the party: "that heightened hysterical edginess of the sort of nightmare it is possible to have where your eyes are open and everything in the scene is familiar" (MMV 205). What has produced this feeling in Siegel has been, ostensibly, Lucy's confession, an absurdist's melange of musical beds, poison pen letters, barroom brawls and David Brennan sitting in a tree. What the girl's confession displaces, however, is something much closer to fear and that is Siegel's own memory of himself at thirteen "sitting shivah on an orange crate":

he still remembered Miriam's husband cursing Zeit the doctor, and the money wasted on the operations, and the whole AMA, crying unashamed in this dim hot room with the drawn shades; and it had so disquieted young Siegel that when his brother Mike had gone away to Yale to take pre-med he had been afraid that something would go wrong and that Mike whom he loved would turn out to be only a doctor, like Zeit, and be cursed someday too by a distraught husband in rent garments in a twilight bedroom. (MMV 196)

Siegel had "often thought that if ... the whole host of trodden-on and disaffected who had approached him ... were placed end to end" they would reach back to that boy. And to death and behind death to a greater fear: "he had always known that for a healer - a prophet actually ... there is no question of balance sheets or legal complexity, and the minute you became involved with anything like that you are something less; a doctor or a fortune-teller" (MMV 196). Siegel here is making the same distinction between healer and doctor and prophet and priest that Joseph Campbell (The Mask of God: Primitive Mythology) makes between priest and shaman:

The priest is the socially initiated, ceremonially inducted member of a recognized religious organization, where he holds a certain rank and functions as the tenant of an office that was held by others before him, while the shaman is one who, as a consequence of a personal psychological crisis, has gained a certain power of his own. ${ }^{15}$

Siegel at age thirty has become a priest, designated such by Lupescu-"You are now the host" - and, as such, he lacks the power to redeem. He can only helplessly and with a rising sense of disgust listen to the hopeless "wondering why ... he should have ever regarded himself as any kind of healer."

But the source of his disgust is some fearful thing which lies deeper than the inane behavior of his flock. Boorishness, stupidity, and promiscuity may be deserving of punishment, but death at the hands of a displaced and psychotic Indian is too extreme. Also, their behavior at least on the surface, does not account for the feeling of uncanny dread which the situation arouses in Siegel and in the reader. Dread has other sources. According to 
Freud, dread or the uncanny is "nothing else than a hidden, familiar thing that has undergone repression and then emerged from it." 16 But not every. thing that is repressed will give rise to the uncanny. Freud states that the uncanny has two sources. The first is archaic animistic beliefs, particularly those concerning the dead. In this context, the double (mirrors, shadows, guardian spirits, and doppelgängers) is particularly uncanny since it "was originally an insurance against destruction to the ego, an 'energetic denial of the power of death." "17 Lupescu recognizes this aspect of the double when he addresses Siegel as both his shadow and his deliverance. Pynchon is clearly familiar with the double as literary convention as it is described by Otto Rank in the second chapter of his book, The Double, and it is something Pynchon will make use of in later works. Often it will be the alter-ego quality of connected but opposing worlds as in "Entropy" or "Lowlands" or the alter-ego of the doppelgänger itself as in Katje Borgesius of Gravity's Rainbow as the blonde ice maiden or the raven haired Domina Nocturna; the relationship between Katje and Gottfried, "his face, ascending, tightening, coming in so close to what she's been seeing all of her life in mirrors;" the white Tchitcherine pursuing his black half-brother Enzian in order to kill him even though Enzian's death will mean death of another kind for him; or the Herrero "Ndjambi Karunga:" God is creator and destroyer, sun and darkness, all sets of opposites brought together, including black and white, male and female $(G R, 100)$. Mirrors will also figure as with V's lover, Melanie l'Heuremaudit in love with her own reflection in $V$.; in Katje's first appearance at the White Visitation in a room full of mirrors in Gravity's Rainbow; or in The Crying of Lot 49 when Oedipa Mas awakens one morning "sitting bolt upright, staring into the mirror at her own exhausted face." The double in "Mortality and Mercy in Vienna," though comic as it manifests itself in Lupescu's first appearance, is uncanny if only by the sheer weight of Pynchon's language:

he would shake his head like a drunk/who is trying to stop seeing double, having become suddenly conscious of the weight of the briefcase and the insignificance of its contents and the stupidity of what he was doing out here ... following an obscure but clearly marked path through a jungle. (MMV 195)

The jungle here is a reference to Conrad's Heart of Darkness and it is the horror which Kurtz has seen which Siegel, by the end of the story, will see as well:

It occurred to him now that Lupescu's parting comment had been no drunken witticism; but that the man really had, like some Kurtz, been possessed by the heart of a darkness in which no ivory was ever sent out of from the interior, but instead hoarded jealously by each of its gatherers to build painfully, fragment by fragment, temples to the glory of some imago or obsession, and decorated inside with the art work of dream and nightmare, and locked finally against a hostile forest, each "agent" in his own ivory tower, having no windows to look out of, turning further and further inward and cherishing a small flame behind an alter. (MMV 212)

It is a closed, sick, and static world, a familiar image in Pynchon: Callisto's 
apartment in "Entropy," Dennis Flange's house in "Lowlands," the siege party in $V$., the deadend suburban streets of The Crying of Lot 49 and in Gravity's Rainbow, the Annubis, Blicero's menage a trois at Peenemunde, Frans Pökler's isolation in Mittelwerke, Zwólfkinder, the Dora Complex concentration camp, and the White Visitation itself. Siegel ends this passage by looking at the crowd and muttering "Oh you're a fine group." And this is perhaps the weakest point in the story for these people need to have committed a sin great enough to bear the weight of their awful punishment, great enough to deflect guilt away from Siegel for leaving them, great enough to turn Loon into an avenging Father killing his own children. If one interprets their behavior in a strictly Freudian way, their sin is great enough because what the guests at the party are guilty of is not simply disgusting behavior but incest.

According to Freud, another source of the uncanny are repressed infantile desires. Primary among these desires is the desire to possess the mother and kill the father. Closely related to this desire is the child's desire to kill the brother and the father's desire to kill the child in an effort to wholly possess the mother. ${ }^{18}$ Something of this sort is happening in Lucy's confession in the endless and convoluted squabbles between various men over various women one of which ends in near murder:

but Harvey had to fly into a rage at Paul because he knew I was in love with Paul ... and he chased Paul for seven blocks through the theater district one night with a boatswain's knife. That was sort of funny too because Harvey was in uniform and it took four SP's finally to bring him down, and even then he broke the arm of one of them and sent another to Bethesda Naval Hospital with severe abdominal wounds. (MMV 204)

Two sins have been collapsed into one. Harvey has attacked his brother, another sailor, and his father, the Shore Patrol. And the attack is highly sexual both in motive and in the form it takes. The boatswain's knife is phallic and abdominal wounds are alarmingly close to the genitals thus bringing to mind the myth of Kronos in which Kronos kills his father, cuts off his genitals, and throws them into the sea. Harvey's act is also generalized. It becomes the act of the group because of Lucy's tendency to speak in long paratactic sentences giving equal weight to all things from murder to pawning a baritone sax. And because members of the group try to murder each other, in a sense blood kin, Loon's psychosis, itself particulary dreadful because its victims kill and eat their own families, becomes the outward and substanital manifestation of the group's own inward and spiritual sickness.

Since the group seems symptomatic of whatever is wrong with the larger society (the choice of the nation's capital as the place where the story occurs would encourage such an interpretation), the Windigo psychosis becomes emblematic of a larger sickness. Irving Loon's name is both a pun and an allusion. "Loon" is, of course, slang for lunatic. "Irving" points to A. Irving Hallowell, noted anthropologist and an expert on Ojibwa culture. Given 
Hallowell's theories concerning logo-centricism in culture (Culture and Experience, University of Pennsylvania Press, 1955) and some of Pynchon's later concerns, particularly the episode about the New Turkic alphabet in Gravity's Rainbow - "the first kill-the-police-commisioner signs (and somebody does! this alphabet is really something!)" (GR 355-56)-it is tempting to cite Hallowell as a source, but Pynchon's source here is more likely an article by Ruth Landes, "The Abnormal among the Ojibwa Indians" published in the Journal of Abnormal and Social Psychology, Vol. 33, 1938. According to Landes, Ojibwa culture, impoverished, competitive, isolated, and driven by an "insistent need for food, and by the insistent fear of failure" is a breeding ground for paranoia. She says that "the hunter feels himself to be a man at bay, fighting cosmic forces which he personalizes as cynical or terroristic." 19 Siegel's college anthropology teacher, Professor Mitchell, echoing her words, once lectured:

Out in the wilderness, with nothing but a handful of beaver, deer, moose and bear between him and starvation, for the Ojibwa hunter, feeling as he does at bay, feeling a concentration of obscure cosmic forces against him and him alone, cynical terrorists, savage and amoral deities ... which are bent on his destruction, the identification becomes complete. When such paranoid tendencies are further intensified by the highly competitive life of the summer villages at ricing or berry-picking time, or by the curse, perhaps, of a shaman with some personal grudge, the Ojibwa becomes highly susceptible to the well-known Windigo psychosis. (MMV 208)

Lupescu's party is the Ojibwa summer village in another form. Professor Mitchell had emphasized the competitive aspects of the Ojibwa village. Debbie Considine emphasizes the sexual; "Blasts, brawls, sex orgies, community sings, puberty rites" (MMV 207). Lupescu's party is tense with both. Debbie is an object of general lust. Lucy hates her for it. People listen to music, play craps, sing filthy limericks, throw each other through the apartment's French windows in a parody of the sex act and dump their feelings of guilt and anxiety on Siegel. These feelings are those of the society in general. A decade before, Professor Mitchell had said, " "The Ojibwa ethos is saturated with anxiety,' and simultaneously 50 pens copied the sentence verbatim" (MMV 208). Ruth Landes, in her article had made the comparison between Ojibwa culture and ours direct: "Every society is not equally provocative of psycho-neurosis and in many cultural milieus grave disorders do not flourish to the same marked extent as among the Ojibwa or ourselves." 20 Insanity, specifically clinical paranoia, is at the center of this story and Washington, D.C., headquarters of the DIA, the NSA, the CIA, the FBI, the Secret Service, the Pentagon and, in the 1950's, the McCarthy Era witch hunts, is an ideal place for it. The city is also the political center of the country, both cosmopolitan and middle-class, and thus the disease spreads. Siegel himself, with his flashbacks and visions, is a psychotic episode waiting to happen: 
he was beginning to feel jovial, irresponsibly so; a light-headedness which he realized might be one of the first stages of hysteria. (MMV 200)

As priest, Siegel is Lupescu's mirror. As psychotic, he is Loon's.

Paranoia is a standard theme and device in Pynchon, particularly in The Crying of Lot 49 and Gravity's Rainbow. Pynchon encourages this state of mind in the reader by creating totally bizarre situations which are nevertheless based on fact. The Windigo psychosis in "Mortality and Mercy in Vienna" is a real and documented psychosis, just as in $V$. the Herrero massacre is based on a real historical event. In Gravity's Rainbow the White Visitation really did exist. During World War II it was called the Special Operations Executive. ${ }^{21}$ Along with the meticulous attention to detail and historical accuracy, however, will be things that either don't quite fit or are based on popular mythology. The drug slang in Gravity's Rainbow, for example, is from the late 1960's not the mid 1940's. ${ }^{22}$ And the alligators in the sewer in $V$. are merely a product of the popular imagination analogous to the french fried rats at MacDonald's or the fingers in the Heinz pickle jar. "Mortality and Mercy in Vienna" was written by someone who knows Washington, D.C. and knows that the heavy spring rains and the cherry blossoms come out around Easter, that Dupont Circle where Lupescu has his apartment is both Embassy Row and where hipsters, Beats, and later hippies would gather, and that Washington is a city peculiar for its rootlessness and its odd combination of cosmopolitan sophistication and middle class provincialism. There is, however, in Washington no theater district.

But the reference to "theater district" (Lucy's confession, MMV 204) points up the theatricality of these people, this place, this situation, and contributes to the fine hysterical edge Siegel is feeling. And, since even for a person not familiar with Washington, the phrase "theater district" should produce a slight jar, it helps to blur the distinction between what is real and what is not. This blurring will be developed further in Pynchon's novels as in the Scwartzkommando episode in Gravity's Rainbow where Pisces Headquarters counterfeits a film about a Black unit in the German army only to find out later that it really existed.

Paranoia is also embedded in the language. It is not only in the way Siegel describes his own state of mind (MMV 205, 212), but is also in a complex series of puns and allusions. For example, when Lupescu addresses Siegel as "Mon semblable ... mon frère," he is quoting the last line of Part I of T.S. Eliot's The Waste Land. This itself is a reference to the Preface to Baudelaire's Fleurs du Mal in which Baudelaire lists the evils which beset him including the most monstrous one of all, Ennui. Part of what Siegel is suffering from is ennui-"a girl fellow junior diplomats had sworn was a sure thing had turned out to be so much more than sure that in the end it had not been worth the price of drinks" (MMV 195). The lines of Eliot's poem immediately preceding the last, "Oh keep the Dog far hence, that's friend to men, / Or 
with his nails he'll dig it up again!" refer to the Dirge in Webster's White Devil, "But keep the wolf far hence, that's foe to men." Lupescu's name in Italian, "lupesco," means "wolfish" and is entymologically related to "Lupercus," the Lycean Pan, a god associated with fertility and thus related to the dema. Lupescu is a dema or Christ figure. His first name is David. Christ is of the House of David. Lupescu is also host and enemy, an office he gives to Siegel, and as such is like the dog "that's friend to men" and the wolf "that's foe." Another character, Harvey Duckworth, arrives carrying the underage Lucy piggyback (the pig again). His last name is the last name of Virginia Woolf's half brother, George, who had sexually molested her when she was a child. Lucy introduces herself right after Siegel decides that a limerick about "a young fellow named Cheever who had an affair with a beaver" has a "Deeper Human Significance" (a paranoid maneuver in and of itself) and was "gilded with a certain transcendental light which reminded him of that final trio from Faust" (MMV 201). Lucy's name, Lucy or Lucia, means "light." The beaver is what Ojibwas eat, what Windigos see instead of people, and American slang for the female genitals. Comparing the limerick to Faust collapses, like the figure of the pig, the sacred into the profane. Faust sold his soul to the devil which is, structurally, what Siegel does when he leaves these people because of what he knows and they don't. Siegel is also half Jesuit, an intellectual order with Faustian connotations for many Protestants. Debbie Considine, Loon's beaver in more ways than one, is referred to by Siegel as "Marrone," Italian for "chestnut" and Italian slang for "gross blunder." Given her habit of picking up men all over the world, bringing them back to Washington and then abandoning them, sleeping with her is a gross blunder. She also commits one by cueing in Siegel as to what is really wrong with Irving Loon.

There is also a trap laid for the unwary critic in the incest motif. Given the numerous references to Freud, "Vienna" in the title is one, it is tempting to interpret the story in light of Freud's Totem and Taboo. The people in the story may be seen as members of two totem clans. Lupescu, Siegel, and Loon are of the pig clan. Everyone else is a beaver. According to Freud, societies which are organized in this way have two basic taboo prohibitions, "namely, not to kill the totem animal, and to avoid sexual intercourse with totem companions of the other sex." ${ }^{23}$ In Freudian terms, the totem animal is the Father and the three father figures in this story, the pig as totem animal, Siegel (he and Lupescu are, in essence, the same) as father confessor, and Loon, if only because of his size, ("ten feet tall with fists like rocks" (MMV 207). Anyone who has ever seen John Wayne charging across the railroad tracks to kill his foster son in Howard Hawks' 1948 Red River will get the connection) are all threatened in some way. The pig is dead but, given its function in the story, it seems to have been a sacrifice which united "the participants with each other and with their god." ${ }^{24}$ Its murder was ritual and not taboo. Harvey Duckworth, however, is at one point hurling pistachio 
nuts at it, Siegel is going mad, and Loon is in exile. Everyone else at the party, that is, all the beavers, spend a lot of time playing musical beds. This interpretation will work, up to a point, but folds in the absence of a definitive and unobtainable mother figure.

Pynchon's paranoia, his habit of setting up patterns which go nowhere, allusions which are purely structural, and conspiracies which make no sense, such as in Stencil's quest in V., the Potsage system in The Crying of Lot 49, and most of what is in Gravity's Rainbow, has been written about extensively. His basic techniques for developing and writing about paranoia were fairly well established even in this early story and later works can be seen as refinements of this one. Pynchon has also established here one of his most basic themes because this story is about Siegel's personal psychological crisis, his realization of his own human limitations, his own mortality, which, according to Freud, is the most deeply repressed and fervently denied truth human beings know. This realization of human limitations and human mortality as a theme will become painfully intense in Gravity's Rainbow with the worrying the characters do over the Poisson distribution, in the Advent section- "As if it were you who could, somehow save him" (GR 136)-and in the Rocket which will, finally, drop on us all. Helplessness is the common denominator in Callisto ("Entropy") who cannot save the bird, in Kurt Mondagon $(V$.) who can only watch the Herreros die, in Oedipa Maas (The Crying of Lot 49) who can do nothing for the old sailor, and in Frans Pökler (Gravity's Rainbow) who, in a gesture of wrenching futility, gives his wedding ring to a woman dying in a concentration camp: "If she lived, the ring would be good for a few meals, or a blanket, or a night indoors, or a ride home. ..." (GR 433).

Some critics, most notably Tony Tanner in his essay " $V$. and $V-2$," have seen each of Pynchon's, individual works as part of a series. ${ }^{25}$ This view is extreme and misleading; Gravity's Rainbow is not an extension of $V$., but it does point to one characteristic of Pynchon's fiction. Each individual work is best considered as part of a larger whole, and images, themes, and patterns which are subtle and bewildering in the later works become clear when read in the context of all his works. For example, the pig, the most omnipresent image in Pynchon's fiction, ceases to puzzle the reader when it is understood that when Pynchon uses a pig he is talking about the dema and the whole complex of ideas clustered around the dema. This combined with his systematic deconstruction of causality indicates an effort on his part to steer the reader away from a linear concept of time, purposive and pointing toward a final judgment, toward a cyclical view. The writing does not simply stop. It comes around again to the beginning. "Mortality and Mercy in Vienna" does not simply end. It comes around to a beginning, forcing the reader to consider Siegel's position in the society he has just abandoned. Siegel is not an outsider no matter how alienated he might feel. $\mathrm{He}$ is one of them and their faults are his. When he leaves he takes them with him. Nothing has been purged; no one, not even Siegel, has been saved. 
The reader, forced to consider the question of Siegel's culpability, arrives at no answer. The horror does not end with the story; it internalizes in the reader and is left to fester.

\section{NOTES}

1 Jorge Luis Borges, "From Somebody to Nobody," in his Other Inquisitions, trans. Ruth L.C. Simms (New York: Washington Square Press, 1965), p. 156.

2 See Chapter Five in Sigmund Freud, Interpretation of Dreams, (New York: Avon Books, 1965).

3 Roland Barthes, S/Z, trans. Richard Miller (New York: Hill \& Wang, 1974), p. 5.

4 Wolfgang Iser, The Act of Reading (Baltimore: The Johns Hopkins University Press, 1978), pp. 228-30.

5 Iser, p. 230.

6 Barthes, p. 5.

7 Stanley Fish, "Literature in the Reader: Affective Stylistics," in Reader Response Criticism, ed. Jane P. Tompkins (Baltimore: The Johns Hopkins University Press, 1980), p. 81.

8 Fish, "Interpreting the Variorum," in Reader Response Criticism, p. 166.

9 Sigmund Freud, "The 'Uncanny'," in On Creativity and the Unconscious (New York: Harper and Row, 1958); Otto Rank, The Double, trans. Harry Tucker (Chapel Hill: University of North Carolina Press, 1971); and James G. Frazer, The Golden Bough (New York: Avenel Books, 1981).

10 Frazer, pp. 47.48.

11 Joseph Cambell, The Masks of God: Primitive Mythology (1959; rpt. New York: Penguin Books, 1969), p. 182.

12 Campbell, pp. 182-83.

13 Frazer, pp. 44-51.

14 Freud, "The 'Uncanny'," pp. 123-24.

15 Campbell, pp. 231.

16 Freud, "The 'Uncanny'," p. 153.

17 Ibid., p. 156, p. 141 quoting Otto Rank.

18 Ibid., p. 157.

19 Ruth Landes, "The Abnormal Among the Ojibwa Indians," Journal of Abnormal Social Psychology, 33 (1938), 18.

20 Ibid., p. 14.

21 Paul Fussell, "The Brigadier Remembers," in Pynchon: Twentieth Century Views, ed. Edward Mendelson (New York: Prentice Hall, Inc., 1978), p. 213.

22 Douglas Fowler, A Reader's Guide to Gravity's Rainbow (Ann Arbor, Michigan: Ardis, 1980), p. 179.

23 Sigmund Freud, "Totem and Taboo," in The Basic Writings (New York: Modern Library, 1938), p. 831.

24 Ibid., p. 912.

25 Tony Tanner, "V. and V-2," in Pynchon: Twentieth Century Views, ed. E. Mendelson (New York: Prentice Hall, Inc., 1978). 